\title{
PREVALENCE AND FACTORS ASSOCIATEDWITH PATERNITY INTENTION AMONG MEN LIVING WITH HIV/AIDS IN FORTALEZA, CEARÁ
}

\author{
Cláudia Bastos da Silveira Reis', Maria Alix Leite Araújo², Roumayne Fernandes Vieira Andrade, Angélica \\ Espinosa Barbosa Miranda ${ }^{4}$
}

\footnotetext{
${ }^{1}$ M.Sc. in Collective Health. Nurse at the Neonatal Unit of the Hospital Distrital Gonzaga Mota de Messejana. Fortaleza, Ceará, Brazil. E-mail: claudiabsilveira@yahoo.com.br

${ }^{2}$ Ph.D. in Nursing. Professor at the Mestrado em Saúde Coletiva, Universidade de Fortaleza. Fortaleza, Ceará, Brazil. E-mail: mleite@ unifor.br

${ }^{3}$ M.Sc in Collective Health. Consultant in Gerência de Vigilância em Saúde da Secretaria de Saúde do Estado. João Pessoa, Paraíba, Brazil. E-mail: roumaynefv@hotmail.com

${ }^{4}$ Ph.D. in Public Health. Professor at the Departamento de Medicina Social of the Universidade Federal do Espírito Santo. Vitória, Espírito Santo, Brazil. E-mail: espinosa@ndi.ufes.br
}

\begin{abstract}
The aim of this study was to analyze the prevalence and factors associated with paternity intention in 162 men with HIV/AIDS in Fortaleza, Ceará. Data were collected from June to September 2012 using a questionnaire in reference outpatient centers. Pearson's chi-squared test and logistic regression model were used for analysis. In all, $41.4 \%$ of men had the intention to have children. Age $<35$ years $(p<0.001)$, desire to have children before diagnosis $(p<0.001)$, relationship for less than five years $(p=0.022)$, partner's desire to have children $(p<0.001)$, having no children with the partner $(p=0.047)$, partner without children $(p=0.032)$ and therapy for more than three years $(\mathrm{p}=0.030)$ presented significant statistical association with men's desire to have children. In the multivariate analysis, the desire to have children before diagnosis ( $\mathrm{p}=0.004 ; \mathrm{OR}: 9.81 ; \mathrm{CI}: 1.84-52.20)$ and partner's desire to have children ( $\mathrm{p}<0.001$; OR:9.72; CI:3.48-27.12) remained statistically significant. Many men still intend to be fathers even after the HIV/AIDS diagnosis.

DESCRIPTORS: HIV. Paternity. Sexual and reproductive health. Fertility.
\end{abstract}

\section{PREVALENNCIA E FATORES ASSOCIADOS ÀS INTENÇÕES DE PATERNIDADE EM HOMENS COM HIV/AIDS EM FORTALEZA, CEARÁ}

RESUMO: Objetivou-se analisar a prevalência e os fatores associados às intenções de paternidade em 162 homens com HIV/Aids em Fortaleza, Ceará. A coleta de dados ocorreu de junho a setembro de 2012, por meio de questionário, aplicado em ambulatórios de referência. Para a análise, utilizou-se o teste qui-quadrado de Pearson e o modelo de regressão logística. Tinham intenção de ter filho, $41,4 \%$. Idade inferior a 35 anos $(p<0,001)$, querer filho antes do diagnóstico $(p<0,001)$, tempo do relacionamento inferior a cinco anos $(p=0,022)$, parceiro querer filho $(p<0,001)$, não ter filho com parceiro $(p=0,047)$, parceiro não ter filho $(p=0,032)$ e tempo de terapia superior a três anos $(\mathrm{p}=0,030)$, apresentaram associação estatisticamente significativa para homens desejarem filhos. Na análise multivariada, querer filho antes do diagnóstico ( $p=0,004 ;$ OR: 9,81; IC:1,84-52,20) e parceiro desejar filho ( $<<0,001$; OR:9,72; IC:3,48-27,12) se mantiveram estatisticamente significativas. A intenção de paternidade permanece em muitos homens mesmo após o diagnóstico de HIV/ Aids.

DESCRITORES: HIV. Paternidade. Saúde sexual e reprodutiva. Fertilidade.

\section{PREVALENCIA Y FACTORES ASOCIADOS CON LA INTENCIÓN DE TENER HIJOS EN LOS HOMBRES QUE VIVEN CON VIH/SIDA EN FORTALEZA, CEARÁ}

\begin{abstract}
RESUMEN: Se objetivó analizar la prevalencia y factores asociados con intenciones de paternidad en 162 hombres con VIH/SIDA en Fortaleza, Ceará. Los datos fueron recopilados entre junio y septiembre de 2012 utilizando un cuestionario en ambulatorios de referencia. Se utilizó Prueba $\chi^{2}$ de Pearson y modelo de regresión logística para análisis. Tenían la intención de tener hijos, $41.4 \%$. Menores de 35 años ( $p<0,001)$, deseo de tener hijos antes del diagnóstico $(p<0,001)$, relación $<$ cinco años $(p=0,022)$, deseo de pareja de tener hijos $(p<0,001)$, no tener un hijo con su pareja $(p=0,047)$, pareja no tener hijos $(p=0,032)$ y terapia $>$ tres años $(p=0,030)$ se asociaron con el deseo de tener hijos. En el análisis multivariante, deseo de tener hijos antes del diagnóstico ( $p=0,004 ;$ OR:9,81; IC:1,84-52,20) y deseo de pareja de tener hijos ( $\mathrm{p}<0,001 ;$ OR:9,72; IC:3,48-27.12) se mantuvo estadísticamente significativa. Intención de paternidad se mantuvo en muchos hombres incluso después del diagnóstico de VIH/SIDA.
\end{abstract}

DESCRIPTORES: VIH. Paternidad. Salud sexual y reproductiva. Fertilidad.

Texto Contexto Enferm, Florianópolis, 2015 Out-Dez; 24(4): 1053-60. 


\section{INTRODUCTION}

Infection by HIV/AIDS is still a complex public health problem, in spite of the advancements conquered in terms of prevention and treatment. By the end of 2013, there were 35 million people with HIV around the world, 3.2 million of them being children and 2.1 million adolescents. ${ }^{1}$ Most of the people who live with HIV lead a fully sexual active and reproductive life. ${ }^{2}$ For this reason, they keep their intention to have children and fulfill this desire, which drew attention from health service providers to the paternity/maternity issue.

Historically, women have always been the main responsible for reproductive issues; however, over the last several years, this has been changing and men are becoming active subjects in this process. ${ }^{3}$ The intention to have children is present in people's lives regardless of their sex, ${ }^{3-4}$ and the fact that they live with HIV. ${ }^{5-6}$ Nevertheless, when one with HIV/AIDS expresses this intention, the idea is usually not very well accepted and creates controversy among health care professionals, who have difficulty understanding it as a right that must be respected and taken into consideration by health care policy makers. ${ }^{4}$

This change among people who live with HIV/AIDS regarding their desire to have children has occurred mainly due to the advent of the antiretroviral therapy. The use of this therapy has, in addition to increasing survival rate and improving quality of life, led many people with HIV to make plans for their future, including the plan to have children. ${ }^{4,7}$ Studies have also shown the effectiveness of the antiretroviral therapy in reducing vertical transmission (VT) when applied during the pregnancy of women with HIV..$^{8-9}$

Although living with HIV has deep implications in the conception process, ${ }^{3}$ it has not been an impediment to fulfill the desire to have children. ${ }^{10}$ Nevertheless, despite the improvement in quality of life and considerable VT reduction after the advent of the antiretroviral therapy, paternity/ maternity among people with HIV is still a concerning situation due to hindrances in access to the prophylactic measures necessary to prevent VT. ${ }^{3}$

In order for the reproduction process to occur under safe circumstances, i.e., free from HIV, reproductive rights must be respected and strategies must be made available to ensure early diagnosis and the necessary conditions for adequate follow up. On the other hand, people must be aware of the possibility of VT and their decision must be made in the safest, most conscientious possible way. ${ }^{3}$
In general, studies addressing the theme of conception among people with HIV/AIDS are scarce and more focused on women or the couple. In face of the complexity and relative scarcity of studies that address the intention to have children among men with HIV, the aim of this study was to analyze the prevalence and factors associated with the intention to have children among men with HIV/AIDS in the city of Fortaleza, state of Ceará, Brazil.

\section{METHODS}

Cross-sectional research conducted in the city of Fortaleza, at two outpatient centers of reference hospitals for the care of people with HIV/ AIDS. One of them is connected to the Secretaria de Saúde do Estado do Ceará and the other to the Universidade Federal do Ceará (UFC). These institutions were selected because they were responsible for $93 \%$ of the notifications and follow-up of the HIV / AIDS cases in Fortaleza. ${ }^{11}$

The population of the study was made up of men with HIV/AIDS who were assisted at the outpatient centers of the aforementioned hospitals, regardless of the duration of their treatment.

The sample was calculated considering a total of 3,115 cases of AIDS among people older than 20 years of age who resided in Fortaleza between 2000 and $2008,{ }^{11} 6.9 \%$ prevalence of pregnancy in women with HIV, ${ }^{12} 99 \%$ confidence interval, and $5 \%$ sample error. The sample needed consisted of 162 men. For the calculation of the sample, we considered the notifications of AIDS cases among men over 20 years of age and women in fertile age (20 to 49 years old) in the city of Fortaleza. ${ }^{11}$

The period between 2000 and 2008 was chosen due to the availability, by the Brazilian Unified Health System (SUS, as per its acronym in Portuguese) of the antiretroviral therapy, which guaranteed access by people who live with HIV/ AIDS to treatment. The sample was distributed proportionally between the two services, considering the percentage of notifications.

The study included men with HIV/AIDS diagnosis, regardless of whether they had a partner and their sexual orientation, aged 18 years old or above. Those who had had a vasectomy were disregarded.

The collection of data occurred in the period between June and September 2012, via a questionnaire applied by a researcher together with two nursing scholarship students who were duly 
trained. The questionnaire consisted of social, demographic and behavioral variables, HIV/AIDS diagnosis and treatment data, data about sexual partners and health care provider, and questions that addressed the intention to have children. Men were invited to participate in the study while they were waiting to receive care at the outpatient center. In case they agreed, they were led to a private place and the questionnaire was applied.

Data were processed using the statistical program Statistical Package for the Social Sciences (SPSS), version 19.0. Descriptive analysis was conducted using the distribution of frequency for the categorical variables and calculation of mean, as well as standard deviation for numeric variables. In the bivariate analysis, Pearson's chi square test was used, as well as Fisher's exact test when applicable, to analyze statistical associations, establishing a 5\% significance level and a 95\% confidence level. After that, those whose value was $p<0.05$ were analyzed in the program Data Analysis and Statistical Software (STATA), version 11.0, using the multivariate logistic regression model. The dependent variable was defined as the intention to have children among men diagnosed with HIV/ AIDS.

Ethical aspects concerning research involving human beings were respected, according to the recommendations by Resolution 196/96 of Brazil's National Health Council. The research proposal was approved by the Research Ethics Committee of Hospital São José de Doenças Infecciosas, as per protocol n. 047/2008, and by the Committee of the Walter Cantídio University Hospital, under protocol n. 042.06.12. Data were only collected once the interviewees had signed a Free and Informed Consent Term.

\section{RESULTS}

Of the 162 men interviewed, 67 (41.4\%) stated the intention to have children; of these, 53 $(79.1 \%)$ said their main reason for it was the desire to form a family.

Their age varied from 18 to 67 years old (mean: 39.7; SD:10.2) and most of them were above 40 years of age $(48.8 \%)$. Regarding education, 89 $(54.9 \%)$ had ten or more years of schooling; 156 (96.3\%) said they had a religion; 91 (56.2\%) had paid occupations; 143 (88.3\%) began their sex lives at the age of 18 or younger; and 120 (74.1\%) remained sexually active (Table 1 ).
Table 1 - Social and demographic data about men with HIV/AIDS receiving care at reference outpatient centers. Fortaleza, Ceará, Brazil, 2012

\begin{tabular}{|c|c|c|c|}
\hline Variables & Mean (SD) & $\mathbf{n}$ & $\%$ \\
\hline Age range (years) & $39.7(10.2)$ & & \\
\hline$\leq 29$ & & 30 & 18.5 \\
\hline $30-39$ & & 53 & 32.7 \\
\hline$\geq 40$ & & 79 & 48.8 \\
\hline Schooling (years) & $9.53(4.2)$ & & \\
\hline$\leq 4$ & & 21 & 13.0 \\
\hline $5-9$ & & 52 & 32.1 \\
\hline$\geq 10$ & & 89 & 54.9 \\
\hline \multicolumn{4}{|l|}{ Religion } \\
\hline Catholic & & 121 & 74.7 \\
\hline Other & & 35 & 21.6 \\
\hline Not religious & & 6 & 3.7 \\
\hline \multicolumn{4}{|l|}{ Studying } \\
\hline Yes & & 19 & 11.7 \\
\hline No & & 143 & 88.3 \\
\hline \multicolumn{4}{|l|}{ Working } \\
\hline Yes & & 91 & 56.2 \\
\hline No & & 71 & 43.8 \\
\hline $\begin{array}{l}\text { Personal income (minimum } \\
\text { wage) }^{*}\end{array}$ & $1.37(1.2)$ & & \\
\hline None & & 31 & 19.1 \\
\hline$\leq 1$ & & 70 & 43.2 \\
\hline$>1$ & & 61 & 37.7 \\
\hline $\begin{array}{l}\text { Family income (minimum } \\
\text { wage) }\end{array}$ & $2.31(2.0)$ & & \\
\hline None & & 8 & 4.9 \\
\hline$\leq 1$ & & 58 & 35.8 \\
\hline$>1$ & & 96 & 59.3 \\
\hline \multicolumn{4}{|l|}{$\begin{array}{l}\text { Beginning of sexual activity } \\
\text { (years of age) }\end{array}$} \\
\hline$\leq 18$ & & 143 & 88.3 \\
\hline$>18$ & & 17 & 10.5 \\
\hline Ignored & & 2 & 1.2 \\
\hline \multicolumn{4}{|l|}{ Remaining sexually active } \\
\hline Yes & & 120 & 74.1 \\
\hline No & & 42 & 25.9 \\
\hline Total & & 162 & 100.0 \\
\hline
\end{tabular}

"Current minimum wage - BRL 788.00 per month

A total of $72(44.4 \%)$ already had children (mean:1.56; SD: 0.49) and 23 (31.9\%) stated that their children were born after their HIV diagnosis. Four (17.4\%) had children with HIV. Eighty (49.4\%) said they were heterosexuals; 66 (40.7\%) were homosexuals; and 16 (9.9\%) were bisexuals. The ones who had a steady partner were 92 (56.8\%); of these, 65 (70.7\%) lived with their partners. The partners of $37(40.2 \%)$ men were diagnosed with HIV (data not shown in the tables). 
Most of the interviewees - 129 (79.6\%) said they were not diagnosed with AIDS at the time of the interview and $33(20.4 \%)$ had some opportunistic infection. The vast majority - 146 $(90.1 \%)$ - was undergoing antiretroviral therapy; of these, $86(58.9 \%)$ had been undergoing treatment for more than three years. Seventy-four $(45.7 \%)$ had been hospitalized before; the majority, $49(66.2 \%)$, had been hospitalized one year or less before the interview (data not shown in the tables).

Table 2 shows an analysis of the social demographic data, relating them to the intention to have children. We identified that being 35 years old or younger was the only variable that had a statistically significant association among the men with HIV/AIDS who wanted to have children ( $p<0.001 ;$ OR:4.62; CI:2.21-9.67).

Table 2 - Analysis of the social and demographic data associated with the intention to have children among men with HIV/AIDS. Fortaleza, Ceará, Brazil, 2012

\begin{tabular}{|c|c|c|c|c|}
\hline \multirow{2}{*}{ Variables } & \multicolumn{4}{|c|}{ Intention to have children among men with HIV/AIDS } \\
\hline & Yes $(\%)$ & No (\%) & OR (CI 95\%) & $p$ \\
\hline \multicolumn{5}{|c|}{ Age range (years) } \\
\hline$>35$ & $28(41.8)$ & $73(76.8)$ & $4.62(2.21-9.67)$ & $<0.001$ \\
\hline$\leq 35$ & $39(58.2)$ & $22(23.2)$ & 1 & \\
\hline \multicolumn{5}{|l|}{ Origin } \\
\hline Different city & $30(44.8)$ & $36(37.9)$ & $0.75(0.37-1.49)$ & 0.380 \\
\hline Fortaleza & $37(55.2)$ & $59(62.1)$ & 1 & \\
\hline \multicolumn{5}{|c|}{ Schooling (years) } \\
\hline$>5$ & $59(88.1)$ & $75(78.9)$ & $1.96(0.76-5.52)$ & 0.131 \\
\hline$\leq 5$ & $8(11.9)$ & $20(21.0)$ & 1 & \\
\hline \multicolumn{5}{|l|}{ Studying } \\
\hline Yes & $9(13.4)$ & $10(10.5)$ & $0.75(0.25-2.25)$ & 0.571 \\
\hline No & $58(86.6)$ & 85 (89.5) & 1 & \\
\hline \multicolumn{5}{|l|}{ Working } \\
\hline Yes & $37(55.2)$ & $54(56.8)$ & $1.06(0.54-2.10)$ & 0.838 \\
\hline No & $30(44.8)$ & $41(43.2)$ & 1 & \\
\hline \multicolumn{5}{|c|}{ Personal income (minimum wage) ${ }^{*}$} \\
\hline$>1$ & $35(37.3)$ & $36(37.9)$ & $1.02(0.51-2.06)$ & 0.940 \\
\hline$\leq 1$ & $42(62.7)$ & $59(62.1)$ & 1 & \\
\hline \multicolumn{5}{|c|}{ Family income (minimum wage) ${ }^{*}$} \\
\hline$>1$ & $41(61.2)$ & 55 (57.9) & $0.87(0.43-1.73)$ & 0.674 \\
\hline$\leq 1$ & $26(38.8)$ & $40(42.1)$ & 1 & \\
\hline
\end{tabular}

"Current minimum wage - BRL 788.00 per month

Wanting children before the HIV diagnosis ( $\mathrm{p}<0.001$; OR:17.64; CI:5.10-92.5), time of relationship of five years or less ( $\mathrm{p}=0.022$; OR:2.65; CI: 1.05-6.74), having a partner who wants children ( $\mathrm{p}<0.001$; OR:9.99; CI:3.48-29.2), not having children with the current partner ( $\mathrm{p}=0.047$; OR:2.60;
CI:0.91-7.84), and having a partner who does not have children from a previous relationship $(\mathrm{p}=0.032 ; \mathrm{OR}: 2.60 ; \mathrm{CI}: 0.99-7.00)$ were the variables that had a statistically significant association among the men who wanted to have children (Table 3). 
Table 3 - Relations between intention to have children and behavioral variables related to the sex partners of men with HIV/AIDS. Fortaleza, Ceará, Brazil, 2012

\begin{tabular}{|c|c|c|c|c|}
\hline \multirow[t]{2}{*}{ Variables } & \multicolumn{4}{|c|}{ Intention to have children among men with HIV/AIDS } \\
\hline & Yes $(\%)$ & No $(\%)$ & OR (CI 95\%) & $p$ \\
\hline \multicolumn{5}{|l|}{ Sexual orientation $(n=162)$} \\
\hline Homosexual & $25(37.3)$ & $41(43.2)$ & $1.27(0.64-2.55)$ & 0.456 \\
\hline Heterosexual/Bisexual & $42(62.7)$ & $54(56.8)$ & 1 & \\
\hline \multicolumn{5}{|l|}{ Has children $(n=162)$} \\
\hline Yes & $26(38.8)$ & $46(48.4)$ & $1.48(0.74-2.94)$ & 0.225 \\
\hline No & $41(61.2)$ & $49(51.6)$ & 1 & \\
\hline \multicolumn{5}{|c|}{ Wanted children before diagnosis $(n=162)$} \\
\hline No & $03(4.5)$ & $43(45.3)$ & $17.6(5.10-92.5)$ & $<0.001$ \\
\hline Yes & $64(95.5)$ & $52(54.7)$ & 1 & \\
\hline \multicolumn{5}{|l|}{ Lives with partner $(\mathrm{n}=92)$} \\
\hline No & $15(35.7)$ & $12(24.0)$ & $0.56(0.20-1.54)$ & 0.219 \\
\hline Yes & $27(64.3)$ & $38(76.0)$ & 1 & \\
\hline \multicolumn{5}{|l|}{ Time of relationship $(\mathrm{n}=92)$} \\
\hline$>5$ & $16(38.1)$ & $31(62.0)$ & $2.65(1.05-6.74)$ & 0.022 \\
\hline$\leq 5$ & $26(61.9)$ & $19(38.0)$ & 1 & \\
\hline \multicolumn{5}{|c|}{ Partner wants children $(\mathrm{n}=92)$} \\
\hline No & $11(22.0)$ & $39(78.0)$ & $24.7(348-29.28)$ & $<0.001$ \\
\hline Yes & $31(73.8)$ & $11(26.2)$ & 1 & \\
\hline \multicolumn{5}{|c|}{ Has children with current partner $(n=92)$} \\
\hline Yes & $8(19.0)$ & $19(38.0)$ & $2.60(0.91-7.84)$ & 0.047 \\
\hline No & $34(81.0)$ & $31(62.0)$ & 1 & \\
\hline \multicolumn{5}{|l|}{ Partner has HIV (n=92) } \\
\hline Yes & $19(45.2)$ & $18(36.0)$ & $0.68(0.27-1.71)$ & 0.368 \\
\hline No/Does not know & $23(54.8)$ & $32(64.0)$ & 1 & \\
\hline \multicolumn{5}{|l|}{ Partner has children $(\mathrm{n}=92)$} \\
\hline Yes & $11(26.2)$ & $24(48.0)$ & $2.60(0.99-7.00)$ & 0.032 \\
\hline No & $31(73.8)$ & $26(52.0)$ & 1 & \\
\hline \multicolumn{5}{|c|}{ Partner knows about the participant's diagnosis $(\mathrm{n}=92)$} \\
\hline Yes & $39(92.9)$ & $45(90.0)$ & $0.69(0.10-3.83)$ & 0.459 \\
\hline No & $3(7.14)$ & $05(10.0)$ & 1 & \\
\hline
\end{tabular}

In Table 4, the analysis of questions that referred to diagnosis and treatment showed that the variable time of antiretroviral therapy longer than three years ( $\mathrm{p}=0.030 ; \mathrm{OR}: 2.10 ; \mathrm{CI}: 1.01-4.36)$ had a statistically significant association with the intention to have children among men with HIV/ AIDS. 
Table 4 - Intention to have children among men with HIV/AIDS related to diagnosis and treatment data. Fortaleza, Ceará, Brazil, 2012

\begin{tabular}{|c|c|c|c|c|}
\hline \multirow{2}{*}{ Variables } & \multicolumn{3}{|c|}{ Intention to have children among men with HIV/AIDS } & \multirow[b]{2}{*}{$p$} \\
\hline & Yes $(\%)$ & No $(\%)$ & OR (CI 95\%) & \\
\hline \multicolumn{5}{|c|}{ Had AIDS (n=162) } \\
\hline Yes & $29(43.3)$ & $39(41.0)$ & $0.91(0.46-1.80)$ & 0.776 \\
\hline No & $38(56.7)$ & $56(58.9)$ & 1 & \\
\hline \multicolumn{5}{|c|}{ Uses ART* $(n=162)$} \\
\hline No & 07 (10.4) & $09(9.5)$ & $0.89(0.27-3.00)$ & 0.838 \\
\hline Yes & $60(89.5)$ & $86(90.5)$ & 1 & \\
\hline \multicolumn{5}{|c|}{ Time of ART* (years) $(n=146)$} \\
\hline$\leq 3$ & $29(48.3)$ & $57(66.3)$ & $2.10(1.01-4.36)$ & 0.030 \\
\hline$>3$ & $31(51.7)$ & $29(33.7)$ & 1 & \\
\hline \multicolumn{5}{|c|}{ Was hospitalized $(\mathrm{n}=162)$} \\
\hline Yes & $29(43.3)$ & $45(47.4)$ & $1.17(0.59-2.32)$ & 0.607 \\
\hline No & $38(56.7)$ & $50(52.6)$ & 1 & \\
\hline \multicolumn{5}{|c|}{ Last hospitalization (years) $(\mathrm{n}=74)$} \\
\hline$\leq 1$ & $20(69.0)$ & $29(64.4)$ & $0.81(0.26-2.44)$ & 0.688 \\
\hline$>1$ & $09(31.0)$ & $16(35.6)$ & 1 & \\
\hline \multicolumn{5}{|c|}{ Had children after diagnosis $(n=72)$} \\
\hline Yes & $10(38.5)$ & $13(28.3)$ & $0.63(0.20-1.99)$ & 0.373 \\
\hline No & $16(61.5)$ & $33(71.7)$ & 1 & \\
\hline
\end{tabular}

In the adjusted multivariate analysis, the fact that the partner wants to have children $(\mathrm{p}<0.001$; OR: 9.72; CI: 3.48-27.12) and wanting children before the HIV diagnosis ( $p=0.004$; OR: 9.81; CI: 1.84-52.20) were the variables that kept a statistically significant association with the intention to have children (Table 5).

Table 5 - Multivariate analysis of the intention to have children among men with HIV/AIDS. Fortaleza, Ceará, Brazil, 2012

\begin{tabular}{lcc}
\hline Variables & OR (CI 95\%) & $p$ \\
\hline Partner wants children & & \\
$\quad$ No & $9.72(3.48-27.12)$ & $<0.001$ \\
$\quad$ Yes & 1 & \\
Wanted children before & & \\
diagnosis & & \\
$\quad$ No & $9.81(1.84-52.20)$ & 0.004 \\
$\quad$ Yes & 1 & \\
\hline
\end{tabular}

\section{DISCUSSION}

The prevalence of men who wanted children even after their HIV diagnosis was similar to that found in other studies. ${ }^{2,13}$ These findings stress the fact that the intention of conceiving a child is a reality in people's lives, regardless of whether they live with the HIV infection or not. ${ }^{5}$ Most of the time, the infection can postpone that intention but it cannot eliminate it. ${ }^{14}$ In the context of HIV / AIDS infection, however, reproduction raises controversial issues in view of the implications involved. ${ }^{14-16}$

Younger men who had been undergoing antiretroviral therapy for more than three years had a stronger intention to have children. This situation is possibly related to the fact that they had not fulfilled their desire to become fathers, as well as to the fact that their health status and quality of life had improved as a result of the antiretroviral therapy, which can also be seen in other studies. ${ }^{7,4}$

Wanting children before the HIV diagnosis and the partner's desire to have children were factors that kept influencing the paternity process. Studies with men and women with HIV show that the reasons for wanting children differ between the sexes ${ }^{5}$ and are strongly influenced by the partner's desire. ${ }^{5-6}$

What one can verify is that the fact that one lives with HIV is not an impediment to fulfill the dream of becoming a mother/father, and that can happen safely as long as one has access to treatment and methods of assisted reproduction. ${ }^{17}$ These alternatives have been increasing patients' life expectancy and the possibility to conceive safely. ${ }^{18}$

It is noteworthy that assistance in family planning, as well as reproductive counseling to 
patients who receive care from HIV/AIDS outpatient centers are more targeted at women. In South Africa, it was clear that professionals recognized the sexual and reproductive rights of people with HIV/ AIDS. However, they faced conflicts between guaranteeing these rights and preventing HIV dissemination, ${ }^{19}$ and attention was more focused on women. ${ }^{20}$

For cultural and/or structural reasons, men were, for many years, virtually excluded from health care services and involvement with reproductive matters. ${ }^{21}$ Only more recently have we seen the creation of public health care policies directed at this population. ${ }^{22}$

Health care providers must pay special attention to men who live with HIV/ AIDS and want to have children, since they may feel excluded and discriminated against on account of HIV. This situation becomes more serious in face of their desire to have children considering how unprepared health care service providers are to embrace these specific demands.

For this reason, the desire to have children among men with HIV/AIDS deserves special attention by public policy makers and health care professionals, considering that the desire to have children after diagnosis has proven to be a meaningful experience, which justifies the fact that people who plan to undergo this experience overcome difficulties. ${ }^{23}$

Health care professionals struggle with this idea and allege that it involves risks. ${ }^{19}$ Additionally, they disregard the individuality, respect to sexuality and subjectivity involved in this process.

This study has some limitations. Because it is a cross-sectional study, it did not take into account subjective questions that are involved in paternity, which can directly influence the desire to have children. Another limitation is that it deals with a touchy subject which is difficult to address, and this may have influenced the participants' answers. Nevertheless, we believe that the interviewers were duly trained to address the questions, which mitigated this bias. On the other hand, we were particularly engaged in developing an interaction with interviewees in order to create a relaxing atmosphere for the interview. We also asked clear questions that allowed for an open dialogue when doubts arose. In spite of these limitations, we highlight the relevance of the study due to the fact that the theme is largely undocumented when it comes to men.

From these findings, we have some recom- mendations that aim at contributing for the elaboration of public health care policies directed toward people who live with HIV/AIDS, especially men, who are usually an invisible population to health care providers: ${ }^{21}$ To conduct ongoing training for health care professionals through participative workshops where they can express and discuss their limitations in accepting conception among people with HIV / AIDS; health care centers should divulge and guarantee the reproductive rights of people who live with HIV/AIDS; to provide for family planning services and methods, as well as counseling about reproduction in order to assist people who live with HIV/AIDS in conceiving, while reducing the probability of vertical transmission and helping them make safer decisions.

\section{CONCLUSION}

This study showed that wanting children is a reality in some men's lives, even after they have been diagnosed with HIV / AIDS, and that this decision is complex and influenced by several factors.

The aspects that are strongly connected to a man's desire to have children were having a partner with the same intention and wanting children before the diagnosis. The possibility of becoming a father must be respected among men with HIV/ AIDS and understood as a right. Health care services should provide for the mitigation of risks and support these men.

\section{REFERENCES}

1. Joint United Nations Program on HIV/AIDS (UNAIDS). The Gap Report. Geneva: UNAIDS/ WHO; 2014. [acesso 2015 Mar 20]. Disponível em: http://www.unaids.org/sites/default/files/en/ media/unaids/contentassets/documents/unaidspublication/2014/UNAIDS_Gap_report_en.pdf

2. Demissie DB, Tebeje B, Tesfaye T. Fertility desire and associated factors among people living with HIV attending antiretroviral therapy clinic in Ethiopia. BMC Pregnancy Childbirth. 2014 Nov 20; 14: 382.

3. Withers M, Dworkin S, Harrington E, Kwena Z, Onono M, Bukusi E, et al. Fertility intentions among HIV-infected, sero-concordant Kenyan couples in Nyanza Province, Kenya. Cult Health Sex. 2013 Jul; 15(10):1175-90.

4. Mindry DL, Crankshaw TL, Maharaj P, Munthree C, Letsoalo T, Milford C, et al. We have to try and have this child before it is too late": missed opportunities in client-provider communication on reproductive intentions of people living with HIV. AIDS Care. 2015 Sep; 27(1):25-30. 
5. Matthews LT, Crankshaw T, Giddy J, Kaida A, Smit JA, Ware NC, et al. Reproductive decision-making and periconception practices among HIV-positive men and women attending HIV services in Durban, South Africa. AIDS Behav. 2013 Feb; 17(2):461-70.

6. Cook R, Hayden R, Weiss SM, Jones DL. Desire for fertility among HIV-seroconcordant and-discordant couples in Lusaka, Zambia. Cult Health Sex. 2014 May; 16(7):741-51.

7. Crankshaw TL, Matthews LT, Giddy J, Kaida A, Ware NC, Smit JA, et al. A conceptual framework for understanding HIV risk behavior in the context of supporting fertility goals among HIVserodiscordant couples. Reprod Health Matters. 2012 Dec; 20(39 Suppl):50-60.

8. Leal AF, Roese A, Sousa AS. Medidas de prevenção da transmissão vertical do HIV empregadas por mães de crianças o positivas. Invest Educ Enferm. 2012 Mar; 30(1):44-54

9. Kupek E, Oliveira JF. Transmissão vertical do HIV, da sífilis e da hepatite B no município de maior incidência de AIDS no Brasil: um estudo populacional no período de 2002 a 2007. Rev Bras Epidemiol. 2012 Set; 15(3):478-87.

10. Ngure K, Baeten JM, Mugo N, Curran K, Vusha S, Heffron R, et al. My intention was a child but I was very afraid: fertility intentions and HIV risk perceptions among HIV-serodiscordant couples experiencing pregnancy in Kenya. AIDS Care. 2014 Apr; 26(10):1283-7.

11. Prefeitura Municipal de Fortaleza. Boletim Epidemiológico: Aids, sífilis em gestantes e transmissão vertical da sífilis e do HIV. Fortaleza (CE): Prefeitura Municipal; 2009.

12. Friedman RK, Bastos FI, Leite IC, Veloso VG, Moreira RI, Cardoso SW, et al. Pregnancy rates and predictors in women with HIV/AIDS in Rio de Janeiro, Southeastern Brazil. Rev Saúde Pública. 2011 Apr; 45(2):373-81.

13. Kawale P, Mindry D, Stramotas S, Chilikoh P, Phoya A, Henry K, et al. Factors associated with desire for children among HIV-infected women and men: a quantitative and qualitative analysis from Malawi and implications for the delivery of safer conception counseling. AIDS Care. 2014 Nov; 26(6):769-76.

14. Mmbaga EJ, Leyna GH, Ezekiel MJ, Kakoko DC. Fertility desire and intention of people living with
HIV/AIDS in Tanzania: a call for restructuring care and treatment services. BMC Public Health. 2013 Jan 30; 13:86.

15. Reis RK, Santos CB, Dantas RAS, Gir E. Qualidade de vida, aspectos sociodemográficos e de sexualidade de pessoas vivendo com HIV / AIDS. Texto Contexto Enferm. 2011 Jul-Set; 20(3):565-75.

16. Wanyenze RK, Wagner GJ, Tumwesigyec NM, Nannyonga M, Wabwire-Mangen F, Kamya MR. Fertility and contraceptive decision-making and support for HIV infected individuals: client and provider experiences and perceptions at two HIV clinics in Uganda. BMC Public Health. 2013 Feb 2; 13:98.

17. Taylor TN, Mantell JE, Nywagi N, Cishe N, Cooper D. "He lacks his fatherhood": Safer conception technologies and the biological imperative for fatherhood among recently-diagnosed Xhosaspeaking men living with HIV in South Africa. Cult Health Sex. 2013 Jul; 15(9):1101-14.

18. Gosselin JT, Sauer MV. Life after HIV: examination of HIV serodiscordant couples desire to conceive through assisted reproduction. AIDS Behav. 2011 Feb; 15(2):469-78.

19. Moodley J, Cooper D, Mantell JE, Stern E. Health care provider perspectives on pregnancy and parenting in HIV-positive individuals in South Africa. BMC Health Serv Res. 2014 Sep 12; 14:384.

20. Moore AM, Bankole A, Awolude O, Audam S, Oladokun A, Adewole I. Attitudes of women and men living with HIV and their healthcare providers towards pregnancy and abortion by HIV-positive women in Nigeria and Zambia. Afr J AIDS Res. 2015 Mar; 14(1):29-42.

21. Alves RF, Silva RP, Ernesto MV, Lima AGB, Souza FM. Gênero e saúde: o cuidar do homem em debate. Psicol Teor Prat. 2011 Dez; 13(3):152-66.

22. Ministério da Saúde (BR), Secretaria de Atenção à Saúde, Departamento de Ações Programáticas Estratégicas. Política nacional de atenção integral à saúde do homem: princípios e diretrizes. Brasília (DF): MS; 2009.

23. Maksud I. Silêncios e segredos: aspectos (não falados) da conjugalidade face à sorodiscordância para o HIV/AIDS. Cad Saúde Pública. 2012 Jun; 28(6):1196-204. 